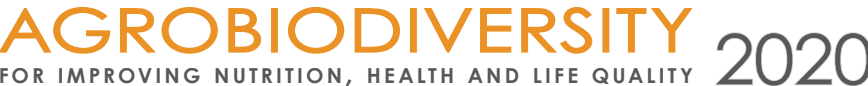

e

\section{PRO-HEALTH AND FUNCTIONAL PROPERTIES OF GOJI BERRY (LYCIUM SPP.)}

\author{
Szot Iwona ${ }^{1,2 *}$, Zhurba Mykhailo ${ }^{3}$, Klymenko Svitlana ${ }^{3}$ \\ ${ }^{1}$ University of Life Sciences, Faculty of Horticulture and Landscape Architecture, Lublin, Poland \\ ${ }^{2}$ Institute of Horticultural Production, Subdepartment of Pomology, Nursery and Enology, Lublin, Poland \\ ${ }^{3}$ M.M. Gryshko National Botanical Garden of Ukraine, National Academy of Sciences, Kyiv, Ukraine
}

Received: 8. 11. $2020 \quad$ Revised: 13. 11.2020 Published: 20. 11. 2020

Goji (Lycium L.) fruit has been an important element of traditional Chinese medicine for centuries. In Asian countries, they are used as an essential component of a healthy diet, a source of many nutrients. Due to their health-promoting properties and chemical composition (phenolic acids, flavonoids, proanthocyanidins, coumarins, tannins, carotenoids, anthocyanins), they deserved the term superfruit. In recent years, goji berries have also become very popular in Europe and America. The fruit is used primarily after drying and is available in the form of various supplements. Two species of Lycium barbarum L. and Lycium chinense Mill. are cultivated on a larger scale. These species are closely related to each other. They differ slightly in morphological features. L. chinense leaves are longer and wider than L. barbarum. L. chinense fruits are slightly smaller and more elongated. There are several less specific species and botanical varieties in natural sites in central and western China, such as L. barbarum var. aurantiocarpum, L. chinense var. potaninii, L. ruthenicum, L. truncatum. Not only fruits contain biologically active substances, but also other parts of plants, especially leaves. This review highlights the healing properties of the fruits and leaves of these species. The most valuable and most interesting component of goji berries is the water-soluble bioactive polysaccharide complex LBP (Lycium Barbarum Polysaccharides) playing an important therapeutic role. The LBP complex has a beneficial effect on the functions of the immune system, inhibits the growth of cancer cells, has antioxidant properties, improves the function of the digestive tract, well-being and sleep quality. Due to the presence of LBP, goji fruit extracts have a hypoglycemic effect, lowering the content of lipids in the blood serum. The diversity of their use as food, medicinal and cosmetic agents was shown.

Keywords: goji berries, Lycium barbarum, Lycium chinense, health benefits

\section{Introduction}

Nowadays, underutilized and less-known species, such as Pseudocydonia sinensis Schneid. (Monka et al., 2014; Grygorieva et al., 2020), Morus nigra L. (Kucelova et al., 2016), Ziziphus jujuba Mill. (Ivanišová et al., 2017), Diospyros virginiana L. (Grygorieva et al., 2018), Sambucus nigra L. (Horčinová Sedláčková et al., 2018), Asimina triloba L. (Brindza et al., 2019),

\footnotetext{
*Corresponding author: Iwona Szot, University of Life Sciences, Faculty of Horticulture and Landscape Architecture, 28 Głęboka Street, 20-612 Lublin, Poland szoti@autograf.pl
} 
Chaenomeles japonica (Thunb.) Lindl. (Klymenko et al., 2019) ect., are becoming more and more well-known for scientific and laic public (Klymenko et al., 2017). One of them is the genus Lycium L., which belongs to the family nightshade (Solanaceae) includes about 88(97) species found in temperate and subtropical climates (Levin et al., 2011; Barboza et al., 2016). Several of them: Lycium barbarum L., L. chinense Mill., L. ruthenicum Murray have been recognized in eastern medicine for over 4,000 years and are popularly called Gouqi in China, and Goji berries, Wolfberry, Christmas berry, Desert-thorn, Matrimony vine, Duke of Argyll's tea tree in other countries of the world. There are also a few less popular botanical species and varieties of natural sites in central and western China, e.g. L. barbarum var. aurantiocarpum, L. chinense var. potaninii, L. truncatum (Zhang et al., 2001). In South Europe there are L. europaeum L., L. intricatum Boiss., Sounth Africa (L. afrum L.), and South and Central America (L. chinense Bert., L. horridum Thunb., L. pallidum Miers. (Seneta and Dolatowski, 2012; Yao et al., 2018).

The first L. barbarum plantations were established over 600 years in China, in Ningxia Hui Autonomous Province, mainly in Zhongning. Fruits from this region are considered to be of a particularly high quality due to optimal soil and climatic conditions, such as sunshine, the sum of effective temperatures, large amplitude between day and night temperatures. An excellent substrate is flood plains with a lot of humus (Wang et al., 2015).

Currently, from the beginning of the $21^{\text {st }}$ century, the cultivation of Goji berries has become very popular due to the numerous beneficial properties of compounds contained in fruits, leaves, root and bark. These compounds delay the aging processes, improve eyesight, liver and kidney function, and generally have a positive effect on the well-being and immunity of the body (Dong et al., 2009; Amagase and Farnsworth, 2011). In search of ways to increase the profitability of farms, growers decide to cultivate new plant species. In European countries: Italy, Serbia, Bulgaria, Poland, there is a growing interest in commercial cultivation. Bulgarian cultivars of L. barbarum (JB1, JB2, JBX, and JB4) are recommended. Also outside Europe, there is an interest in the wider cultivation of Goji berries. In Korea, when examining the suitability for the cultivation of some natural forms and selected cultivars, differences in growth, the habit of shrubs, yield, and fruit shape were observed. Cultivar Yosong 2 (L. chinense) turned out to be the most promising. L. barbarum cultivars are bred in the USA and Canada: Crimson Star, Phoenix Tears and Sask Wolfbery. Plants, due to their high frost resistance, tolerate even large, down to $-30{ }^{\circ} \mathrm{C}$ temperature drops in winter. They have low requirements concerning the position - they grow well and bear fruit, when planted in weaker sandy and permeable soils. They grow worse on heavy, loamy and wet soil (Marosz, 2017).

\section{Description of species and their natural range}

The species from which the raw materials for the production of the currently popular "Superfood Goji" are obtained, are those found in the natural flora of China: L. barbarum, L. chinense, and L. ruthenicum (Wanh et al., 2015). The Goji berries occurs in Tibetan valleys and the Himalayas, in areas not contaminated with agricultural chemicals and civilization pollution. Currently, it is also commonly grown in countries with milder and subtropical climate, e.g. in Japan, Korea, but the raw material obtained there has a lower nutritional and medicinal value (Qian et al., 2004). Wolfdogs are shrubs up to three meters high, arched twigs armed with 


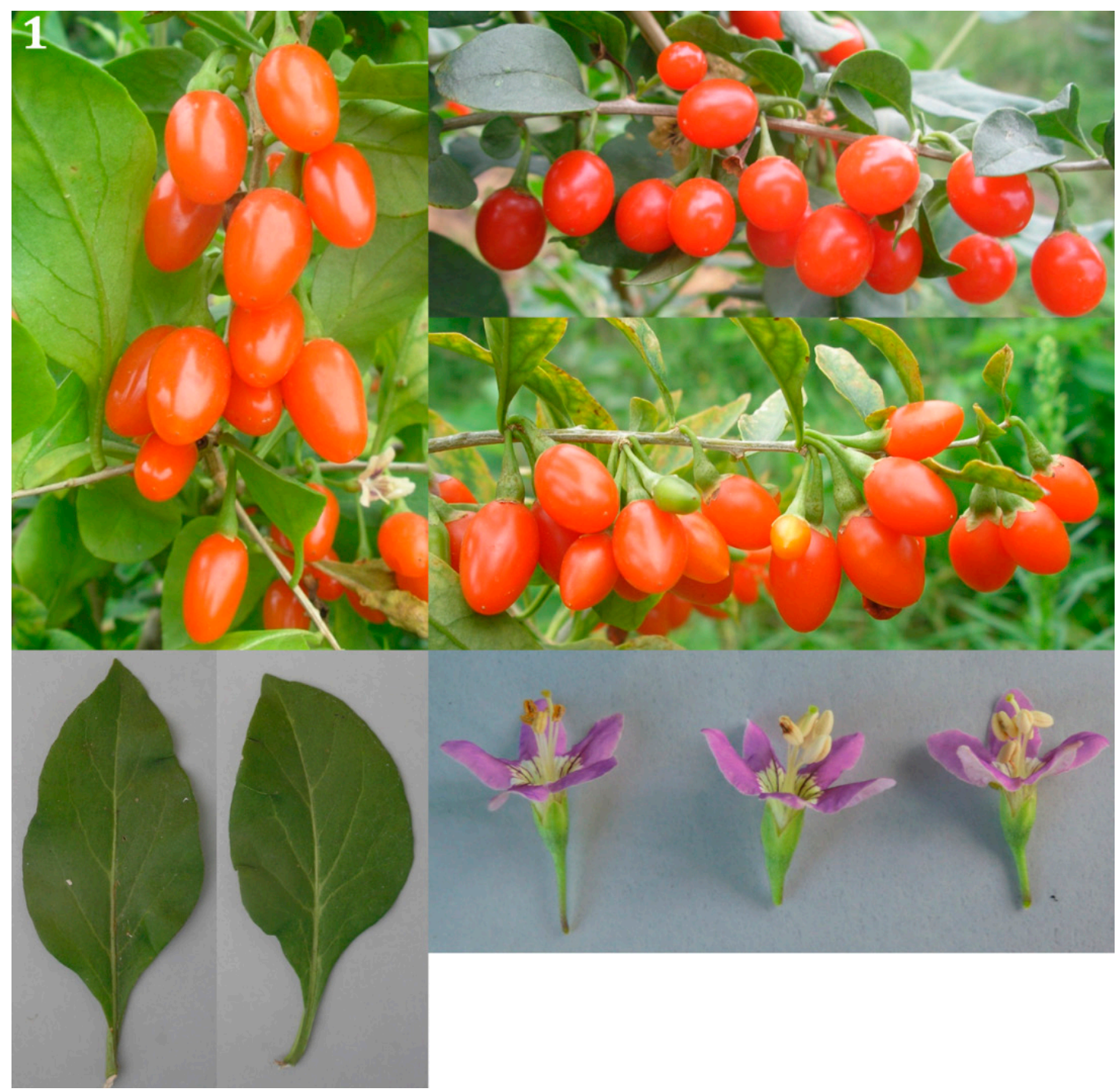

Figure 1 Lycium chinense Mill. (Foto: M. Zhurba, I. Szot)

spikes (the common name boxthorn), small inconspicuous purple flowers, and orange to red fruits (black for L. ruthenicum), which reach up to $2 \mathrm{~cm}$ in length. The first two species are very phylogenetically similar. They grow in the same environment, are harvested at the same time (usually from August to October), and have been used in traditional medicine throughout East Asia for thousands of years (Potterat, 2010). Wetters et al. (2018) showed that the structure of the flower, and specifically the appearance of the crown, is helpful for the morphological differentiation of L. barbarum and L. chinense. The flower tube of L. barbarum is elongated and significantly longer than the petals, L. chinensis crown tube is twice as short as the hairy at the edges petals. The calyx of L. barbarum flowers generally consists of two sepals and in the case of L. chinensis four sepals, however, there are also flowers with only two sepals. Moreover, the seeds of L. barbarum are brownish-yellow and have almost twice as much surface area as 


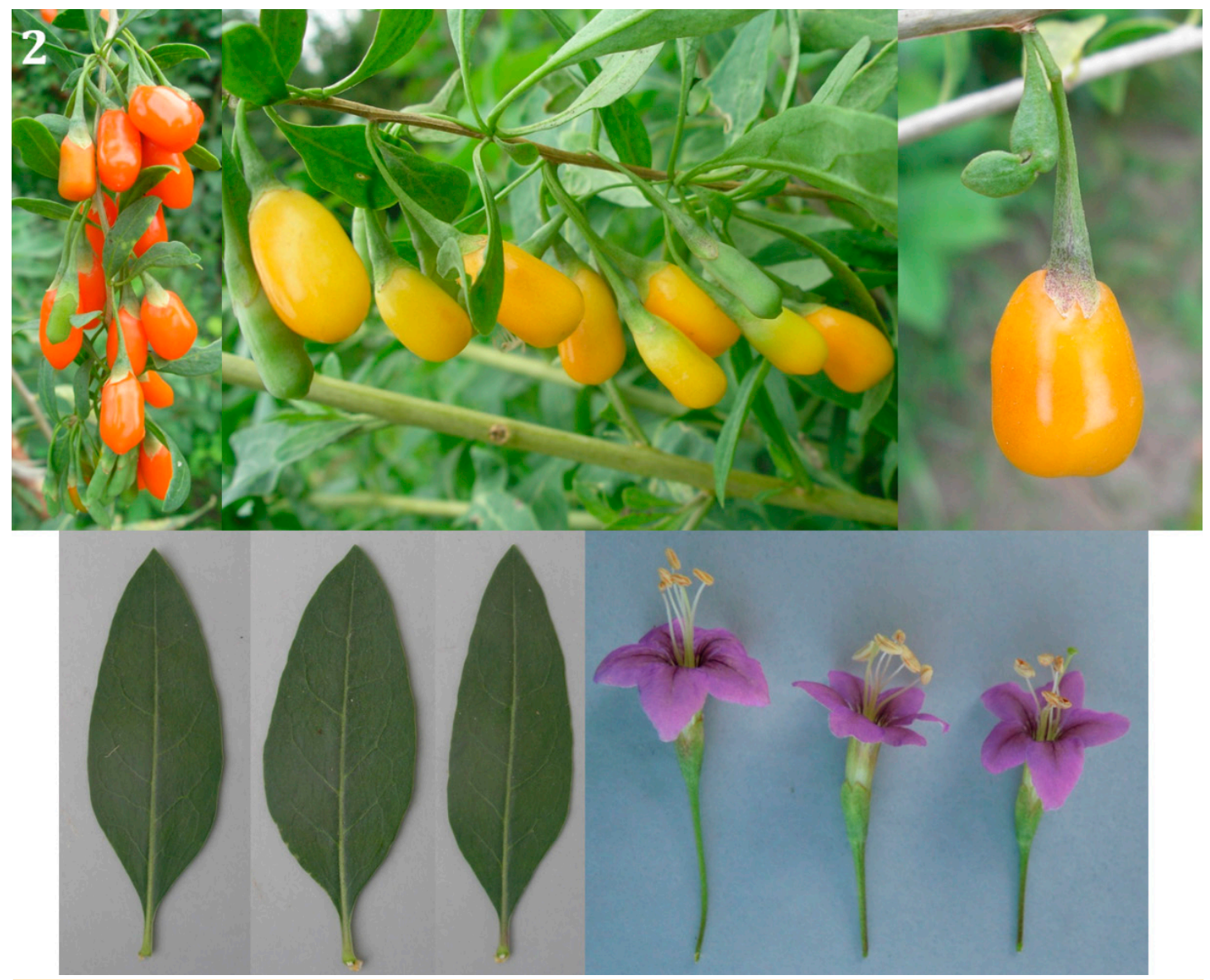

Figure 2

Lycium barbarum L. (Foto: M. Zhurba, I. Szot)

the yellow seeds of L. chinense. L. chinense leaves are up to $4 \mathrm{~cm}$ longer and twice as wide as L. barbarum leaves. These species can also be distinguished by the shape of the fruits. The fruits of L. barbarum and L. chinense are oblong or ovate, the former being red or red-yellow in color and the latter red. The fruits of L. ruthenicum are spherical, purple-black (Wang et al., 2015). Within L. barbarum there are many varieties, in Tibet alone there are 40 (Amagase et al., 2009).

\section{Nutritional properties and bioactive substances found in fruits}

Modern research has confirmed the high nutritional content of goji berries. The dried fruit contained 5.5\% protein (18 amino acids), 26.7\% carbohydrates ( 8 polysaccharides and 6 monosaccharides) including 3.7\% crude fiber and 1\% fat (including 5 unsaturated fatty acids from the omega- 6 group), responsible for the production of hormones and the proper functioning of the brain and nervous system (Qian et al., 2004; Amagase et al., 2009; Bogacz, 2009). Poterańska and Ochmian (2015) report that L. barbarum fruits contain from 12.2-17.6\% of the extract and 1.12-1.3 acids (g/100 g) Consuming L. barbarum fruits provides many health benefits, mainly due to the vitamins they contain. They have a high content of vitamin $\mathrm{C}$, which is fresh fruit is $42 \mathrm{mg} / 100 \mathrm{~g}$, which is comparable to fresh lemon fruits (Toyoda-Ono et al., 
2004). It is assumed that the consumption of only 7 goji berries covers the daily requirement of this vitamin (Amagase and Farnsworth, 2011). A large group of metabolic compounds are carotenoids, the amount of which increases with the ripening of the fruit. They are represented mainly by zeaxanthin and ester derivatives, the content of which in fruits ranges from 0.03 to 0.5\% of dry weight (Inbaraj et al., 2008; Amagase and Farnsworth, 2011). Zeaxanthin is a very important component of the human diet, also provided by some vegetables, the presence of which is particularly important in the macula for the improvement of visual acuity (Cheng et al., 2005). Goji berries are also a source of vitamins $B_{1}, B_{2}, B_{6}$, and $E$ and minerals (phosphorus, calcium, iron, copper, zinc, selenium) (Qian et al., 2004). In the chemical structure of L. barbarum fruits, the most known are water-soluble polysaccharides, the amount of which is estimated at $5-8 \%$ of the dry weight of the fruit, and the molecular weight ranges from 24 to $241 \mathrm{kDa}$ (Peng et al., 2005). In nature, polysaccharide complexes occur naturally as glycoconjugates, e.g. as combinations of glycans (structures made up of sugar units) with proteins or fats. Luo et al. (2004) found 6 monosaccharides in the goji polysaccharide complex: rhamnose, galactose, glucose, arabinose, mannose, and xylose. The analysis showed the presence of 17 amino acids, and the total amino acid content was $8.46 \%$ (Peng et al., 2001). The LBP polysaccharide complex (Lycium Barbarum Polysaccharides) inhibits the growth of cancer cells (He et al., 2012). In studies with experimental animals, the antitumor activity of goji berries against gastric cancer and colon cancer was found (Mao et al., 2010; Mao et al., 2011). During chemotherapy, they play a significant role in protecting the liver cells. In addition, the polysaccharide complex contained in goji fruit has a strong antioxidant activity, which allows inhibiting the aging process (Mao et al., 2011). Due to the presence of LBP, goji berry extracts show a hypoglycemic effect in rabbits with experimental diabetes, while they did not cause such an effect in the organisms of healthy mice. Also, a significant reduction in serum lipids and an increase in HDL cholesterol were found in the organisms of hyperlipidemic rats (Luo et al., 2004). Similar observations were made by Ming et al. (2009) experimenting on mice fed a high-fat diet. They observed a significant reduction in the level of triglycerides, total cholesterol, and LDL fraction, as well as an increase in HDL cholesterol. They also found a drop in blood glucose levels.

The fruit should be eaten regularly but in moderate amounts. Consumption of unripe fruits may lead to poisoning, which is manifested by disturbance of the functions of the digestive tract and the nervous system. In addition, the fruits is are recommended for people taking anticoagulants, pregnant women, and nursing mothers. Side effects of excessive fruit consumption, such as nosebleeds, have been reported (Bogacz, 2009). Increased consumption of goji fruits in Europe has resulted in the emergence of people showing allergic reactions after their consumption (Carnés et al., 2013; Uasuf et al., 2020). Potterat (2010) presented a review based on 150 different reports and does not mention any serious intoxication caused by the consumption of L. barbarum or L. chinense. However, cases or other gastrointestinal complaints may occur in susceptible individuals. In fully ripe goji berries, traces of atropine were found, without any toxicity, up to 19 ppb (Adams et al., 2006).

\section{Health-promoting properties of leaves and other parts of plants}

L. chinense leaves are considered in traditional Chinese medicine as herbs for eternal youth and long life (Soga, 1985), as a nutrient and tonic reducing the risk of arteriosclerosis and 
essential hypertension (Mizobuchi et al., 1964). Among the bioactive substances in the leaves are betaine (Hansel etal., 1992; No et al., 1995) and substances used to reduce the risk of fatness or as a digestive aid for people with insufficient stomach acid production. The leaves contain vitamin C and anti-aging tocopherols (Park, 1995), a group of antioxidant compounds such as rutin, quercetin (Aubert and Kapetanidis, 1989; Duke, 1992; Han et al., 2002), chlorogenic acid (Terauchi et al., 1997). L. barbarum and L. chinense leaves are a valuable source of flavonoids with important antioxidant and antimicrobial properties. Duan et al. (2010) report that the leaves of $L$. barbarum contain gentistic acid (2.5-dihydroxybenzoic acid) with antioxidant properties and enhancing the fungicidal effect of fludioxonil. Grygorieva et al. (2020) studied the content of phenolic compounds in the leaves of several non-traditional crops. The leaves of L. barbarum had the highest content of polyphenols and flavonoids (95.84 mgGAE/g and $54.61 \mathrm{mgQE} / \mathrm{g}$, respectively). Phytochemical studies by Mocan et al. (2014) indicate that the leaves of both species are important sources of flavonoids and chlorogenic acid. L. chinense leaf extract was characterized by a higher antioxidant activity than L. barbarum. Based on antimicrobial tests, it was shown that L. chinense leaf extract was more active than L. barbarum against strains of Gram-positive and Gram-negative bacteria. L. chinense extract against Bacillus subtilis had the best antibacterial activity. Terauchi et al. (1998) noted in L. chinense leaves the presence of lyciumoside I, a methanol extract showing antimicrobial activity against Gram-positive bacilli. Yeh et al. (2008) showed that L. chinense leaf extract stimulates the growth of Pedicoccus bacteria - P. acidilactici, widely used in the dairy industry in the production of yogurt. Dong et al. (2009) compared the chemical composition of L. barbarum from crops to wild plants. They proved that the total content of flavonoids $(21.25 \mathrm{mg} / \mathrm{g}) \mathrm{in}$ the leaves of the cultivated plants was much higher than in the wild $(17.86 \mathrm{mg} / \mathrm{g})$. They therefore, found that the leaves of the crops are more suitable for consumption in salads and as a tea. Liu et al. (2012) investigated the content of polysaccharides in L. barbarum leaves. They found that leaves, like fruits, are a rich source of polysaccharides with immunostimulating properties and should be used more widely in the production of dietary supplements.

\section{Possibilities of use in the food industry}

The fruits of edible wolfberry ( $L$. barbarum, L. chinense) are very delicate. Poterańska and Ochmian (2015), comparing the fruits quality of two L. barbarum cultivars showed that their firmness (172-182 G/mm) is comparable to that of the honeysuckle berry cv. Wojtek $(176 \mathrm{G} / \mathrm{mm})$. The taste of goji fruits is very specific, perceived by some as delicious, similar to licorice (Velder, 1999). Others compare their taste to cranberries with a hint of tomato and herbal flavor, very tart and moderately sweet (Stobnicka et al., 2011). Some cultivars have a less bitter taste. The taste of the fruits is determined by the ratio of the extract to the acidity. The amount of the extract in the fruits is positively correlated with the sugar content. There is more extract, less sour taste is felt. According to the studies by Poterańska and Ochmian (2015), the ratio of extract to acidity of L. barbarum cv. New Bing fruits was 14.7. The fruits are usually used after processing. Most of the fruit is dried immediately after harvesting. Less commonly, they are available frozen. In Western countries, dried goji berries are eaten as a snack, similar to raisins or other dried fruits (Bogacz, 2009). The fruits are also used to make juices and jams. Oil is pressed from the seeds. In Chinese cuisine, dried goji berries are 
boiled before consumption. They are added to rice, soups, chicken, and pork, and mixed with vegetables. The fruits are also cooked as herbal tea, often with the addition of chrysanthemum flower or red tea (Bogacz, 2009). Powdered dried goji berries have a beneficial effect on the physical organoleptic properties, including the flavor and aroma of the bread. Ziemichód and Różyło (2018) showed that the addition of goji berries improved the colour of the bread. With an increase in the addition of dried blueberries in the range of 3-15\%, the hardness of gluten-free bread decreased, and the flexibility increased significantly. For some time, when the term "Superfoods" came up, Goji berries quickly became an established product around the world. Due to the fact that the name Goji is a term that covers a wide variety of closely related plant species, mislabeling and adulteration (unknowingly or intentionally) is possible. In China, dried "Goji" berries are generally L. barbarum, but are sold in different grades: super, "king", "special" and "Grade A" (Wang et al., 2015). This is due to the differences in the size of the berries. The various uses of goji berries in the production of traditional and new products, with the use of innovative technologies, are described by Ye and Jiang (2020). The food industry in China uses the young shoots and leaves of L. barbarum and L. chinense to make salads. In the East, leaves have been used for 2,000 years as an endurance, calming, and thirst-quenching tea (Kim et al., 1997). In addition, the leaves are added to soups and sauces or chopped and fried with eggs (Velder, 1999).

\section{In the pharmaceutical industry}

The herbal industry uses fruits (Lycii Fructus), flowers (Lycii flox), bark (Lycii Cortex), leaves (Lycii Folium), and roots (Lycii radix). The individual parts of the plant, such as leaves, flowers, fruits, and roots, should be harvested at different times of the year, i.e. in spring, summer, autumn, and winter, respectively. In the last decade, goji fruits have been prescribed by dieticians in the form of natural products as a powerful supplement to help lose weight (Carnés et al., 2013). It is available to choose the least processed goji berry products. Unfortunately, the standard procedure in the production of pharmaceuticals using goji powder is the addition of chemical excipients, which are inactive micronutrients devoid of therapeutic effects. They are added to give such products a taste and protect them against the undesirable influence of microorganisms (Vasconcelos et al., 2012). Preservatives, dyes, flavors, sweeteners, thickeners, emulsifiers, and stabilizers are commonly used in pharmaceutical laboratories (Balbani et al., 2006). Moura et al. (2018) used the root meristem of Alliym cepa L. (onion) as an efficient bioassay for the initial screening of the genetic toxicity. They found that industrialized goji berries at all concentrations, including those indicated for use by pharmaceutical companies, had significant potential for toxicity.

\section{In the cosmetics industry}

Cosmetic preparations are applied to the external tissue of our body, which is the skin. They have a nurturing and anti-aging effect, due to their anti-inflammatory properties and protection against excessive water loss. The following active substances of plant origin are used in cosmetics, such as antioxidants, exfoliating substances, moisturizing, brightening or protecting against UV rays. In each part of the plants of the described Lycium species, there are antioxidants, which, according to the free radical theory of aging, are also important in 
skincare. The dominant component with antioxidant properties in the case of L. barbarum are peptidoglycans, also called LB polysaccharides (Zhang, 1993; Qiu et al., 2014), and also vitamin B, C, taurine, and carotenoids in fruits, and rutin in leaves (Jin et al., 2013). Carotenoids are a group of plant pigments that are lyophilic. Due to the fact that these pigments are fat-soluble, they perfectly penetrate the epidermis. Apart from the fact that they neutralize free radicals, they give cosmetics a yellow shade. B vitamins have been used externally to relieve dermatitis, acne, oily hair, and anti-wrinkle creams. Vitamin $\mathrm{C}$ shows anti-radical activity because it reduces the tocopheryl radical and reduces the consumption of vitamin E. Vitamin C after penetrating the stratum corneum, regulates the collagen biosynthesis. It brightens the skin by inhibiting the activity of tyrosine and reducing melanin synthesis. Zhao et al. (2005) applied LB polysaccharides topically to full-thickness human skin explants by a selectively inhibiting metalloproteinase. One of the five major LBPs, LBGp5, was applied to fibroblasts grown under suboptimal conditions. It has been found to stimulate the production of type I collagen and promote cell viability. Plant substances can also have a beneficial effect on wound healing. Several experiments have demonstrated the stimulating effect of LBP on human skin fibroblasts and the role of directional fibroblast migration during wound healing has been explained (Wang et al., 2011; Song et al., 2013; Zhao and Bojanowski, 2015). These experiences justify the advisability of developing the production of cosmetics based on LBP. The seeds contained in the goji fruit contain a cosmetically valuable oil with antiinflammatory properties and improving the skin's protective barrier by reducing epithelial water loss. However, until now cosmetics based on substances derived from Lycium species have not developed on a large scale, mainly due to the lack of registration as a cosmetic raw material in countries such as China and Japan. Another limitation is the high cost of extracting the oil from the fruit due to its low content.

\section{Conclusion}

The fruit, popularly referred to as goji, have been well-established for centuries as a medicine for many ailments: in treatment heart, liver, lung, kidney diseases, and above all as a means of human longevity. Thanks to the content of various bioactive substances such as vitamins, flavonoids, carotenoids, anthocyaninsand theso-called LBP(LyciumBarbarumPolysaccharides) has strong antioxidant, anti-inflammatory properties and regulates carbohydrate and lipid metabolism. The fruit is usually used as a dried raw material. Apart from fruit, other parts of plants, especially leaves, are a rich source of health-promoting ingredients. Currently, there is an intense interest in consumption, and hence in the production of these fruits. Although the highest quality fruit is obtained in the Chinese province of Ningxia, its commercial cultivation is also beginning to develop in other countries. The climatic and soil requirements of the two most important species, L. barbarum and L. chinense, enable their cultivation also in European countries. Of course, it is necessary to select the appropriate variety, which fruits are high quality, i.e. with a high extract-acidity ratio, less tart, yet rich in bioactive substances. As in the case of elderberry and viburnum, goji berries intended for consumption must be fully ripened. Sensitive people, allergy sufferers should consume them in moderation. 


\section{Acknowledgments}

This work was supported by the Visegrad Fund (no. 52011113). Experimental activities were realized in the laboratories of centre of excellence for the conservation and use of agrobiodiversity at the Faculty of Agrobiology and Food Resources, Slovak Agricultural University in Nitra.

\section{References}

ADAMS, M., WIEDENMANN, M., TITTEL, G., BAUER, R. 2006. HPLC-MS trace analysis of atropine in Lycium barbarum berries. In Phytochem. Anal., vol. 17, p. 279-283. https://doi.org/10.1002/pca.915

AMAGASE, H., FARNSWORTH, N.R. 2011. A review of botanical characteristics, phytochemistry, clinical relevance in efficacy and safety of Lycium barbarum fruit (Goji). In Food Res. Intern., vol. 44(7), p. 1702-1717. https://doi.org/10.1016/j.foodres.2011.03.027

AMAGASE, H., SUN, B., BOREK, C. 2009. Lycium barbarum (goji) juice improves in vitro antioxidant biomarkers in serum of healthy adults. In Nutr. Res., vol. 29, p. 19-25. https://doi.org/10.1016/j. nutres.2008.11.005

AUBERT, C., KAPETANIDIS, I. 1989. New flavonoids from Lycium chinense. In Planta Med., vol. 55, 612 p. https://doi.org/10.1055/s-2006-962163

BALBANI, A. P. S., STELZER, L. B., MONTOVANI, J. C. 2006. Excipientes de medicamentos e as informações da bula. In Rev. Bras. Otorrinolaringol., vol. 72(1), p. 400-406. https://doi.org/10.1590/ $\underline{\text { S0034-72992006000300018 }}$

BARBOZA, G.E., HUNZIKER, A.T., BERNARDELLO, G., COCUCCI, A.A., CARIZZO GARCIA, C., FUENTES, V., DILLON, M.O., BITTRICH, V., COSA, M.T., SUBILS, R., ROMANUTTI, A., ARROYO, S., ANTON, A. 2016. Solanaceae. In KADREIT, J. W. and BiITTRICH, V. (eds). The Families and Genera of Vascular Plants, vol. 14: Springer, p. 295-357. https://doi:10.1007/978-3-319-28534-4

BOGACZ, K. 2009. Goji - fruit of health and longevity. In Przem. Ferm. Owoc-Warz., vol. 9, p. 33-43.

BRINDZA, J., GRYGORIEVA, O., KLYMENKO, S., VERGUN, O., MAREČEK, J., IVANIŠOVÁ, E. 2019. Variation of fruits morphometric parameters and bioactive compounds of Asimina triloba (L.) Dunal germplasm collection. In Potravinarstvo Slovak Journal of Food Sciences, vol. 13(1), p. 1-7. https:// doi.org/10.5219/1019

CARNÉS, J., DE LARRAMENDI, C. H., FERRER, A., HUERTAS, A. J., LÓPEZ-MATAS, M. A., PAGÁN, J. A., PEÑA, M. 2013. Recently introduced foods as new allergenic sources: sensitisation to Goji berries (Lycium barbarum). In Food Chem., vol.137(1), 130-135. https://doi.org/10.1016/j.foodchem.2012.10.005

CHENG, C.Y., CHUNG, W.Y., SZETO, Y.T., BENZIE, I.F. 2005. Fasting plasma zeaxanthin response to Fructus barbarum L. (wolfberry, Kei Tze) in a food-based human supplementation trial. In Br. J. Nutr., vol. 93, 1, p. 123-130. https://doi.org/10.1079/bjn20041284

DONG, J. Z., LU, D. Y., WANG, Y. 2009. Analysis of flavonoids from leaves of cultivated Lycium barbarum L. In Plant Foods Hum. Nutr., vol. 64, p. 199-204. https://doi.org/10.1007/s11130-009-0128-X

DUAN, H., CHEN, Y., CHEN, G. 2010. Far infrared-assisted extraction followed by capillary electrophoresis for determination of bioactive constituents in the leaves of Lycium barmarum Linn. In J. Chromarogr A., vol. 1217, p. 4511-4516. https://doi.org/10.1016/j.chroma.2010.04.069

DUKE, J.A. 1992. Handbook of phytochemical constituents of GRASHerbs and other economic plants. CRC Press, Boca Raton.

GRYGORIEVA O., KLYMENKO S., VERGUN O., MŇAHONČÁKOVÁ E., BRINDZA J., TERENTJEVA M., IVANIŠOVÁ E. 2020. Evaluation of the antioxidant activity and phenolic content of Chinese quince (Pseudocydonia sinensis Schneid.) fruit. In Acta Sci.Pol. Technol. Aliment., vol. 19(1), p. 25-36. https://doi.org/10.17306/J.AFS.2020.0738

GRYGORIEVA, O., KUCHARSKA, A.Z., PIÓRECKI, N., KLYMENKO, S., VERGUN, O., BRINDZA, J. 2018. Antioxidant activities and phenolic compounds in fruits of various genotypes of American 
persimmon (Diospyros virginiana L.). In Acta Sci Pol Technol Aliment., vol. 17(2), p. 117-124. https://doi.org/10.17306/J.AFS.0544

GRYGORIEVA, O., VERGUN, O., KLYMENKO, S., ZHURBA, M., HORČINOVÁ SEDLÁČKOVÁ, V., IVANIŠOVÁ, E., \& BRINDZA, J. 2020. Estimation of phenolic compounds content and antioxidant activity of leaves extracts of some selected non-traditional plants. In Potravinarstvo Slovak Journal of Food Sciences, vol. 14, p. 501-509. https://doi.org/10.5219/1314

HAN, S.H., LEE, H.H., LEE, I.S., MOON, Y.H., WOO, E.R. 2002. A new phenolic amide from Lycium chinense Miller. In Arch Pharm. Res., vol. 25(4), 433-437.

HANSEL, R., KELLER, K., RIMPLER, H., SCHNEIDER, G. 1992. Hager'sHandbuch der Pharmazeutischen Praxis. Springer-Verlag, Berlin.

HE, N., YANG, X., JIAO, Y., TIAN, L., ZHAO, Y. 2012. Characterisation of antioxidant and antiproliferative acidic polysaccharides from Chinese wolfberry fruits. In Food Chem., vol. 133, p. 978-989. https:// doi.org/10.1016/j.foodchem.2012.02.018

HORČINOVÁ SEDLÁČKOVÁ, V., GRYGORIEVA, O., VERGUN, O., VINOGRADOVA, Y., BRINDZA, J. 2019. Comparison of selected characteristics of cultivars and wild-growing genotypes of Sambucus nigra in Slovakia. In Biosyst. Divers., vol. 27(1), p. 56-61. https://doi.org/10.15421/011909

INBARAJ, B.S., LU, H., HUNG, C.F., WU, W.B., LIN, C.L., CHEN, B. H. 2008. Determination of carotenoids and their esters in fruits of Lycium barbarum Linnaeus ny HPLC-DAD-AOCI-MS. In J. Pharm. Biomed. Anal., vol. 47, 812-818. https://doi.org/10.1016/i.jpba.2008.04.001

IVANIŠOVÁ, E., GRYGORIEVA, O., ABRAHAMOVÁ, V., SCHUBERTOVÁ, Z., TERENTJEVA, M., BRINDZA, J. 2017. Characterization of morphological parameters and biological activity of jujube fruit (Ziziphus jujuba Mill.). In Journal of Berry research, vol. 7(4), p. 249-260. http://dx.doi.org/10.3233/ IBR-170162

JIN, M., HUANG, Q., ZHAO, K., SHANG, P. 2013. Biological activities and potential health benefit effects of polysaccharides isolated from Lycium barbarum L. In Int J. Biol. Macromol., vol. 54, p. 16-23. https://doi.org/10.1016/j.ijbiomac.2012.11.023

KIM, S.Y., LEE, K.H., CHANG, K.S., BOCK, J.Y., JUNG, M.Y., 1997. Taste and flavor compounds in box thorn (Lycium chinense Miller) leaves. In Food Chem., vol. 58(4), 297-303. https://doi.org/10.1016/ S0308-8146(96)00099-4

KLYMENKO, S., GRYGORIEVA, O., BRINDZA, J. 2017. Less known species of fruit crops. Slovak University of Agriculture in Nitra, 104. https://doi.org/10.15414/2017.fe-9788055217659

KLYMENKO, S., KUCHARSKA, A. Z., SOKÓŁ-ŁĘTOWSKA, A., PIÓRECKI, N. 2019. Determination of antioxidant capacity and polyphenols contents in fruits of genotypes of Chaenomeles japonica (Thunb.) Lindl. In Agrobiodiversity for Improving Nutrition, Health and Life Quality, vol. 3, p. 473483. https://doi.org/10.15414/agrobiodiversity.2019.2585-8246.473-483

KUCELOVA, L., GRYGORIEVA, O., IVANISOVA, E., TERENTJEVA, M., BRINDZA, J. 2016. Biological properties of black mulberry-derived food products (Morus nigra L.). In Journal of Berry Research, vol. 6, p. 333-343. https://doi.org/10.3233/JBR-160141

LEVIN, R., BERNARDELLO, G., WHITING, C., MILLER, J.A. 2011. A new generic circumscription in tribe Lycieae (Solanaceae). In Taxon, vol. 60, p. 681-690.

LIU, H., FAN, Y., WANG, W., LIU, N., ZHANG, H., ZHU, Z., LIU, A. 2012. Polysaccharides from Lycium barbarum leaves: Isolation, characterization and splenocyte proliferation activity. In Int. J. Biol. Macromol., vol. 51, p. 417-422. https://doi.org/10.1016/j.ijbiomac.2012.05.025

LUO, Q., CAI, Y., YAN, J., SUN, M., CORKE, H. 2004. Hypoglycemic and hypolipidemic effects and antioxidant activity of fruit extracts from Lycium barbarum. In Life Sci., vol. 76, p.137-149. https:// doi.org/10.1016/j.lfs.2004.04.056

MAO, F., XIAO, B., JIANG, Z., ZHAO, J., HUANG, X., GUO, J. 2011. Anticancer effect of Lycium barbarum polysaccharides on colon cancer cells involves G0/G1 phase arrest. In Med. Oncol., vol. 28, p. 121126. https://doi.org/10.1007/s12032-009-9415-5 
MAO, Z., XIAO, B., JIANG, Y., GUO, Y., MAO, F., ZHAO, J., HUANG, X., GUO, J. 2010. Growth inhibition and cell-cycle arrest of human gastric cancer cells by Lycium barbarum polysaccharide. In Med Oncol., vol. 27, p. 785-790. https://doi.org/10.1007/s12032-009-9286-9

MAROSZ, A. 2017. Owoce jagody goji (Lycium barbarum i Lycium chinense) - nowe możliwości dla ogrodnictwa czy zagrożenie dla konsumentów? [Fruits of goji berry Lycium barbarum and Lycium chinense - New possibility for horticulture or risk for consumers?] In Ann. Hortic., vol. 26(1), p. 19-30. [in. Polish] https://doi.org/10.24326/ah.2017.1.3

MING, M., GUANHUA, L., ZHANHAI, Y., GUAN, C., XUAN, Z. 2009. Effect of Lycium barbarum polysaccharides administration on blood lipid metabolism and oxidative stress of mice fed high-fat diet in-vivo. In Food Chem., vol. 113, p. 872-777. https://doi.org/10.1016/j.foodchem.2008.03.064

MIZOBUCHI, K.-I., TANIGUCHI, H., KITA, T., INOUE, K., KIMURA, K.,HIGASHI, J. 1964. Studies on the chemical components of box thornseasonal variation of vitamin $\mathrm{C}$ and rutin contents in the leaves of Japanese Lycium chinense. In Annu. Rep. Fac. Pharm., vol. 18(71), p. 27-30.

MOCAN, A., VLASE, L., VODNAR, D.C., BISCHIN, C., HANGANU, D., GHELDIU, A.M., OPREAN, R., SILAGHIDUMITRESCU, R., CRISAN, G. 2014. Polyphenolic content, antioxidant and antimicrobial activities of Lycium barbarum L. and Lycium chinense Mill. leaves. In Molecules, vol. 18, p. 10056-10073. https://doi.org/10.3390/molecules190710056

MONKA, A., GRYGORIEVA, O., CHLEBO, P., BRINDZA, J. 2014. Morphological and antioxidant characteristics of quince (Cydonia oblonga Mill.) and Chinese quince fruit (Pseudocydonia sinensis Schneid.). In Potravinarstvo Slovak Journal of Food Sciences, vol. 8, p. 333-340. https://doi.org/10.5219/415

MOURA D.D., VELOSO C.J., OLIVEIRA V.A., SILVA M., PERON A.P. 2018. Toxicity of the goji berry fruit associated with artificial excipients and dried without additives. In Acta Sci. Biolog. Sci., vol. 40(1), p. 37844. https://doi.org/10.4025/actascibiolsci.v40i1.37844

NO, J.G., PARK, J.S., SEO, G.S. 1995. Composition of chemicalcomponents depending on extracting conditions in a stem and shoot of Lycium chinense. In RDA J. Agric. Sci., vol. 37(1), p. 586-590.

PARK, W.J. 1995. Studies on chemical composition and biological activities of Lycium chinensis Miller. Ph.D. Thesis, Gunkuk University,Seoul, Korea.

PENG, X.M., HUANG, L.J., QI, C.H., ZHANG, Y.X., TIAN, G.Y. 2001. Studies on chemistry and immunomodulating mechanism of glycoconjugate from Lycium barbarum. In Chin. J. Chem., vol. 19, p. 11901197. https://doi.org/10.1002/cjoc.20010191206

PENG, Y., MA, C., LI, Y., LEUNG, K.S.Y., JIANG, Z.H., ZHAO, Z. 2005. Quantification of zeaxantin dipalmitate anf total carotenoids in Lycium fruits (Fructus lycii). In Plant Foods Human Nutr., vol. 60, p. 161-164.

POTERAŃSKA, N., OCHMIAN, I. 2015. The comparison of fruits quality of two goji cultivars (Lycium barbarum). In Badania i Rozwój Młodych Naukowców w Polsce - Nauki Przyrodnicze, p. 125-131.

POTTERAT, O. 2010. Goji (Lycium barbarum and L. chinense): Phytochemistry, Pharmacology and Safety in the Perspective of traditional Uses and Recent Popularity. In Planta Med., vol. 76, p. 7-19. https:// doi.org/10.1055/s-0029-1186218

QIAN, J.Y., LIU, D., HUANG, A.G. 2004. The efficiency of flavonoids in polar extracts of Lycium chinense Mill. Fruits as free radical scavenger. In Food Chem., vol. 87, p. 283-288. https://doi.org/10.1016/j. foodchem.2003.11.008

QIU, S., CHEN, J., CHEN, X., FAN, Q., ZHANG, C., WANG, D., LI, X., CHEN, X., CHEN, X., LIU, C., GAO, Z., LI, H., HU, Y. 2014.Optimization of selenylation conditions for Lycium barbarum polysaccharide based on antioxidant activity. In Carbohydr. Polym., vol. 103, p. 148-153. https://doi.org/10.1016/j. carbpol.2013.12.032

SENETA, W., DOLATOWSKI, J. 2012. Dendrologia [Dendrology]. In Wyd. Nauk. PWN, wyd. 3. p. 279-478. [in Polish]

SOGA, D. 1985. Jooyakudaijiden [Tokoro medicine autobiography], vol. 1, Shogakukan, Tokyo. [in. Japanese] 
SONG, S., HAN, H., KO, U.H., KIM, J., SHIN, J.H. 2013. Collaborative effects of electric field and fluid shear stress on fibroblast migration. In Lab. Chip., vol. 13, p. 1602-1611. https://doi.org/10.1039/ c3lc41240g

STOBNICKA, A., GNIEWOSZ, M., MIETUSZEWSKA, A. 2011. Antibacterial activity of cranberry, seabuckthorn, noni and wolberry juices. In Bromat. Chem. Toksykol., vol. 3, p. 44.

TERAUCHI, M., KANAMORI, H., NOBUSO, M., FUKUDA, S., YAHARA, S.,YAMASAKI, K. 1998. Antimicrobial components in leaves ofLyciumchinenseMill. In J. Food Hygienic Soc. Jpn., vol. 39(6), p. 399-404. https://doi.org/10.3358/shokueishi.39.6399

TERAUCHI, M., KANAMORI, H., NOBUSO, M., YAHARA, S., NOHARA, T. 1997. Detection and determination of antioxidative components in Lycium chinense. In Nat. Med., vol. 51(5), p. 387-391.

TOYODA - ONO, Y., MAEDA, M., NAKAO, M., YOSHIMURA, M., SUGIURA - TOMIMORI, N., FUKAMI, H. 2004. 2-O-(b-D-Glucopyranosyl) ascorbid acid, a novel ascorbid acid analoge isolated from Lycium fruit. In J. Agric. Food Chem., vol. 52, p. 2092-2096. https://doi.org/10.1021/jf035445w

UASUF C.G., ANGELIS E., GUADNANO R., PILOLLI R., D’ANNA C., VILLALTA D., BRUSCA I., MONACI L. 2020. Emerging allergens in goji berry superfruit: The identification of new IgE binding proteins towards allergic patient's Sera. In Biomol., vol. 10, p. 689. https://doi.org/10.3390/biom10050689

VASCONCELOS, P. A. F., ROLIM, L. A., PEIXOTO, M. S. 2012. Influência dos excipientes multifuncionais no desempenho dos fármacos em formas farmacêuticas. [Influence of multifunctional excipients on the performance of drugs in pharmaceutical forms]. In Rev. Bras. Farm., vol. 93(2), p. 136-145. [in Portuguese]

VELDER, P. 1999. The Garden Plants of China. Timber Press, Portland, Oregon, 303.

WANG, X.Y., WANG, Y.G., WANG, Y.F. 2011. Ginsenoside Rb1, Rg1 and three extracts of traditional Chinese medicine attenuate ultraviolet B-induced G1 growth arrest in HaCaT cells and dermal fibroblasts involve down-regulating the expression of p16, p21 and p53. In Photodermatol. Photoimmunol. Photomed., vol. 27, p. 203-212. https://doi.org/10.1111/j.1600-0781.2011.00601.x

WANG, Y., CHEN, H., WU M., SHAOHUA Z. LIU Y., DONG J. 2015. Chemical and genetic diversity of wolfberry. In Lycium barbarum and human health. CHUEN-CHUNG CHANG R., KWOK-FAI S. (ED.) ISBN 978-94-017-9657-6 https://doi.org/10.1007/978-94-017-9658-3 1

WETTERS, S., HORN, T., NICK, P. 2018. Goji who? Morphological and DNA based authentication of "superfood". In Front. Plant Sci., vol 9, p. 1-14. https://doi.org/10.3389/fpls.2018.01859

YE, X., JIANG, Y. 2020. Phytochemicals in goji berries applications in functional foods. CRC Press ISBN 9780367076344

YEH Y.CH. HAHM T.S., SOBLIOV C. M., LO Y.M. 2008. Effects of Chinese wolfberry (Lycium chinese P. Mill.) leaf hydrolates on the growth of Pediococcus acidilactici. In Biores. Techn., vol. 99, p. 1383-1393. https://doi.org/10.1016/j.biortech.2007.01.058

ZHANG, K.Y.B., LEUNG, H.W., YEUNG, H.W., WONG, R.N.S. 2001. Differentiation of Lycium barbarum from its related Lycium species using amplified polymorphic DNA. In Planta Med., vol. 67, p. 379-381. https://doi.org/10.1055/s-2001-14310

ZHANG, X. 1993. [Experimental research on the role of Lycium barbarum polysaccharide in antiperoxidation]. In China J. Chin. Mater. Med., vol. 18(2), p. 110-112.

ZHAO, H., ALEXEEV, A., CHANG, E., GREENBURG, G., BOJANOWSKI, K. 2005. Lycium barbarum glycoconjugates: effect on human skin and cultured dermal fibroblasts. In Phytomed., vol. 12, p. 131-137. https://doi.org/10.1016/j.phymed.2003.08.002

ZHAO, H., BOJANOWSKI, K. 2015. Dermatologic uses and effects of Lycium barbarum. In Lycium barbarum and human health. CHUEN-CHUNG CHANG r., KWOK-FAI S. (ED.) p. 79-84. ISBN 978-94-017-9657-6

ZIEMICHÓD, A., RÓŻYŁO, R. 2018. Effect of the addition of goji berries on the physical properties of gluten-free bread. In Acta Agroph., vol. 25,1, p. 117-127. https://doi.org/10.31545/aagr0010 